\title{
Product Variety, Customisation and Business Process Performance: A Mixed-Methods Approach to Understanding their Relationships
}

\begin{abstract}
This research presents findings from a sequential, mixed qualitative and quantitative method comprising five case studies and a survey of 162 different manufacturing sites where we examined how increases in product variety influence the performance of a wide range of business processes within and across the value chain of engineering, manufacturing, procurement, logistics and sales. We also identified the advantages associated with an increase in product variety and investigated the relationships between business process performance and degree of customisation. Drawing on value chain and resource-based logic, a product variety increase was found to have a differential impact on business processes and was partly contingent on the levels of customisation offered. The results provide both a better understanding of the implications and relative costs associated with product variety increases on key business processes and activities and highlight key areas of business process capability development in order to mitigate the effects of variety increases. The study also provides an example for researchers on the process and advantages of using mixed methods. The results are valuable for manufacturers considering extending their product range in order to provide more choice for customers.
\end{abstract}

Keywords: mixed methods; product variety management; customisation; business processes; value chain

\section{Introduction}

Flexibility-enhancing initiatives have been adopted in order to help manufacturers satisfy their high-variety ambitions (Um et al., 2017). Such approaches can require major changes to the way key business processes are organised. However, increases in product variety can have a positive effect on both sales and market share, but can also have negative consequences for business performance (Syam and Bhatnagar, 2015; Barroso and Giarratana, 2013; Otero-Neira et al., 2010). As Draganska and Jain (2005) commented: "Competitive pressures force firms to provide variety well into the region of exploding costs". For example, higher product variety may increase manufacturing costs through an increase in the complexity of the production process (El Maraghy et al., 2013). It can also cause higher complexity of the demand forecasting process and make obdurate the alignment of supply with demand in the supply chain (Wan and Sanders, 2017; Randall and Ulrich, 2001). The effective management of the business process complexity that arises as a consequence of wide product diversity is core to taking full advantage of the potential gains 
created. Many manufacturers recognise that a trade-off exists between product variety and business performance (Thonemann and Bradley, 2002) but they do not appreciate which of their business activities are impacted most and contribute most to the overall performance profile (El Maraghy et al,. 2013). Much research has accumulated on the relationship between a variety increase and aggregated, business-level performance, but those increasing variety in their products should also consider the impact of product variety on the administrative burden, performance and cost profile of their business processes. It is these key business activities that ultimately cause and explain business performance change (Porter, 1985).

Decisions relating to product variety can be viewed as focusing on how to engineer and manufacture products with the requisite level of customer choice. However, only by extending this focus across a range of business processes can the full implications of product variety be revealed (Ramdas, 2003). It has been argued that manufacturing managers prefer minimal process complexity and oppose product proliferation, whereas marketing managers strive to satisfy diverging customer needs and actively support product proliferation (El Maraghy et al., 2013). The fundamental question concerns the level of variety offered. The solution necessarily concerns the need to assess the benefits in relation to the increased cost and resource burden. We deviate from previous research which has principally focused on the relationship between product variety and aggregated firm performance (Barroso and Giarratana, 2013), or on product variety and supply chain performance (Um et al., 2017, Thonemann and Bradley, 2002). To date, the relationship between a product variety increase and its simultaneous effect on the performance of key business processes, where the origins and impacts of business performance are directly experienced, remains unresearched.

In addition, product variety studies necessarily require product customisation to be considered since the strategic focus of business processes differs according to the levels of 
customisation (that is, from make-to-stock to design-to-order) (Stavrulaki and Davis, 2010; Agarwal et al., 2006). An increase in variety may impact differently on the performance of each business process but this phenomenon is closely related to the required or desired level of product customisation offered (Stavrulaki and Davis, 2010; Agarwal et al., 2006). Our study explores the impact of product variety from the perspective of the general manufacturing firm. Its key aims are as follows:

1) to explore and compare the impact of product variety increases on business process performance; and 2) to examine these impacts according to the levels of customisation offered.

The research makes the following significant contributions. Firstly, it establishes the relative effect of business process performance when product variety is increased. A corollary for this contribution concerns the subsequent implications for business process capability development. Secondly, the research findings explain how different levels of product variety and customisation impact specific aspects of business process performance. The findings have important managerial implications for the adoption of different approaches to product variety under different customisation profiles. The study also provides an example of how a mixed-methods approach can be adopted and the advantages associated with such a research methodology.

\section{Research Background}

\subsection{Product Variety and Product Customisation}

The term 'product variety' is ambiguous as it is used with a number of different conceptual meanings (Stablein et al., 2011). MacDuffie et al. (1996) used the term 'variety' to refer to company choices about the breadth and depth of different product lines in terms of three dimensions: fundamental (different core models and designs at the fabrication and 
design stage), intermediate (different technical options dependent on core design at the assembly stage) and peripheral (particular options and accessories independent of core design at the distribution and sales stage) levels of variety. For example, in an automotive context, fundamental variety typically concerns the mix of platforms, models and body styles, intermediate variety concerns the number of required sub-assemblies such as the number of engine / transmission combinations, and peripheral variety concerns the options which can be chosen without affecting the core design such as seats, sunroof and electric mirrors. Internal variety is commonly regarded as the variance involved in creating the product within a firm or supply chain, while external variety is the amount of different and distinguishable products offered in the marketplace; that is, the variety, or choice, that is available to the customer. In simplistic terms, internal variety is what a manufacturing facility has to deal with, and external variety is what the customer sees (Stablein et al., 2011).

Other approaches to product variety management make reference to 'within-product' and 'across-product' variety offerings. Barroso and Giarratana (2013) refer to versioning as "within-niche product proliferation" as opposed to "across-niche product proliferation" which refers to product breadth. Previously, Martin and Ishii (2002) had also classified two types of variety: spatial variety indicates the variety that a company offers the marketplace at any given point in time, and generational variety which concerns product breadth across different generations of products. Similarly, according to Fisher et al. (1999), product variety can be defined by two attributes: the breadth of the products that a firm offers at any given time and the rate at which the firm replaces existing products with new products.

Variety and customisation are related but distinct concepts. Duray et al. (2000) articulated the difference: "variety provides choice for customers but not the ability to specify the product". A high-variety offering may act as a proxy for customisation but true customisation requires customer involvement in the product specification. An analysis of 
variety necessarily requires the notion of customer involvement and customisation to be considered. Identifying the point of initial customer involvement is critical to determining the degree of customisation (Duray et al., 2000). The earlier the involvement of the customer in the production and supply lifecycle of a product the deeper the level of customisation. Also, a high level of customisation typically leads to high product variety (Agarwal et al., 2006).

A number of researchers have delineated customisation provision into different types, or along a standardisation / customisation continuum. For example, the Lampel and Mintzberg (1996) customisation framework is composed of five positions: pure standardisation, segmented standardisation, customised standardisation, tailored customisation and pure customisation. According to Gilmore and Pine (1997), mass customisation is defined by four discrete approaches: collaborative, adaptive, cosmetic and transparent. Amaro et al. (1999) also highlighted four degrees of product customisation: pure customisation, tailored customisation, standard customisation and non-customisation. The first three types are those used by Mintzberg et al. (1988), while the fourth covers non-custom-made or standard products. Da Silveira et al. (2001) combined a range of different mass customisation frameworks to produce a framework with eight generic levels ranging from pure standardisation to pure customisation and comprising standardisation, usage, packaging and distribution, additional service, additional custom work, assembly, fabrication and design. MacCarthy et al. (2003) developed a taxonomy of operational nodes for mass customisation. Squire et al. (2004) associated the different forms of customisation with four manufacturing functions: distribution, assembly, fabrication and design. Salvador et al. (2004) suggested simple types of special configuration: 'soft' and 'hard' mass customisation. Poulin et al. (2006) extended a previous framework by Montreuil and Poulin (2005) in order to provide a comprehensive view of the degrees of customisation offered to customers. In this case, the 
customisation framework is sub-divided into eight types: popularising, varietising, accessorising, parametering, tailoring, adjusting, monitoring and collaborating. Table 1 provides a summary of the general level of customisation specified by a range of different approaches and contributions.

Table 1. Customisation/standardisation classification systems.

\begin{tabular}{|c|c|c|c|c|c|c|}
\hline $\begin{array}{l}\text { Lampel and } \\
\text { Mintzberg } \\
\text { (1996) }\end{array}$ & $\begin{array}{c}\text { Gilmore } \\
\text { and Pine } \\
(1997)\end{array}$ & $\begin{array}{l}\text { Amaro et al. } \\
\text { (1999) }\end{array}$ & $\begin{array}{l}\text { Da Silveira et } \\
\text { al. (2001) }\end{array}$ & $\begin{array}{l}\text { Squire et al. } \\
\text { (2004) }\end{array}$ & $\begin{array}{l}\text { Salvador et } \\
\text { al. (2004) }\end{array}$ & $\begin{array}{l}\text { Poulin et al. } \\
\text { (2006) }\end{array}$ \\
\hline $\begin{array}{c}\text { Pure } \\
\text { standardisation }\end{array}$ & & $\begin{array}{c}\text { Non } \\
\text { customisation }\end{array}$ & $\begin{array}{c}\text { Standardisation } \\
\text { /Usage }\end{array}$ & & & Popularising \\
\hline $\begin{array}{c}\text { Segmented } \\
\text { standardisation }\end{array}$ & $\begin{array}{l}\text { Adaptive } \\
\text { cosmetic } \\
\text { customizer }\end{array}$ & Standard & $\begin{array}{l}\text { Package and } \\
\text { distribution }\end{array}$ & $\begin{array}{l}\text { Distribution } \\
\text { customisation }\end{array}$ & Soft mass & Varietising \\
\hline $\begin{array}{c}\text { Customised } \\
\text { standardisation }\end{array}$ & & customisation & $\begin{array}{c}\text { Additional } \\
\text { service, custom } \\
\text { work/Assembly }\end{array}$ & $\begin{array}{c}\text { Assembly } \\
\text { customisation }\end{array}$ & customisation & Accessorising \\
\hline $\begin{array}{c}\text { Tailored } \\
\text { customisation }\end{array}$ & & $\begin{array}{c}\text { Tailored } \\
\text { customisation }\end{array}$ & Fabrication & $\begin{array}{l}\text { Fabrication } \\
\text { customisation }\end{array}$ & $\begin{array}{l}\text { Hard mass } \\
\text { customisation }\end{array}$ & $\begin{array}{c}\text { Parametering } \\
\text { Tailoring }\end{array}$ \\
\hline $\begin{array}{c}\text { Pure } \\
\text { customisation }\end{array}$ & $\begin{array}{c}\text { Transparent } \\
\text { customizer } \\
\text { Collaborative } \\
\text { customizer }\end{array}$ & $\begin{array}{c}\text { Pure } \\
\text { customisation }\end{array}$ & Design & $\begin{array}{c}\text { Design } \\
\text { customisation }\end{array}$ & & $\begin{array}{c}\text { Adjusting } \\
\text { Collaborating }\end{array}$ \\
\hline
\end{tabular}

\subsection{Product variety and business process performance}

Increasing the level of product variety offered by a manufacturer creates a number of challenges for engineering and design processes. Milgate (2001) and Jiao et al. (2000) noted that product variety introduces additional complexity by forcing manufacturers to change engineering processes. Investments in new product variants include the costs of product development as each new component has to be designed and tested (Patel and Jayaram, 2013; Fisher et al., 1999). The unit cost of a product also increases with increasing product variety mainly because of the increase in overheads (Ramdas, 2003; Krishnan and Gupta, 2001). 
High product variety causes an escalation in manufacturing costs and increases the complexity of manufacturing processes (Modark et al., 2014; Hu et al., 2011; Scavarda et al., 2010; Alford et al., 2000). A corollary to this is that as product variety increases, the expectation is that the performance of internal operations decreases, as a result of higher direct labour and material costs, manufacturing overhead costs (for example, materials handling, quality control, information systems and facility utilisation), delivery times, and inventory levels (Syam and Bhatnagar, 2015; Patel and Jayaram, 2013; Xia and Rajagopalan, 2009; Salvador et al., 2002; Forza and Salvador, 2001). Manufacturing complexity often leads to a requirement for additional tooling, process areas and floor space owing to the diversity in the number of parts (Fisher and Ittner, 1999). In addition, part variety can increase scheduling complexity by increasing the decision-making challenge associated with when to hold inventory and when to reschedule orders of parts (Bozarth et al., 2009). MacDuffie et al. (1996) noted that as the number and complexity of parts increase, direct labour cost and quality may suffer since production personnel are confronted with a more diverse array of different parts to work with. A consequence of an increase in part variety is that process variety also increases. Process variety is the diversity and complexity in the processes due to process alternatives for each product variant (Zhang et al., 2005).

Product variety increases have also been shown to intensify demand uncertainty (Wan, et al., 2012; Er and MacCarthry, 2003; Randall and Ulrich, 2001) and escalate purchasing process costs (Ulrich 2001). Paradoxically, this can be caused by a reduction in volumes of purchased parts and components (Fisher et al., 1999), which precludes the use of quantity discounts. Benjaafar et al. (2004) examined the effect of increased product variety on inventory costs, and showed that total cost increases linearly with the number of products. Transportation is a significant element of the costs incurred by most global supply chains (Chopra and Meindl, 2007). With low demand for a particular component, typical within a 
high-variety regime, firms are unlikely to achieve economies of scale in transportation, due to shipping less-than-full truck loads (Scavarda et al., 2010). In addition, shipping products with unpredictable demand directly to store can also result in less-than-truck-load (LTL) shipments, so that transportation cost becomes excessive (Lee, 2002).

Tables 2 and 3 provide a full list of relevant, variety-related, value-chain, business process performance literature. Table 2 relates the literature on those business process activities (and implied costs) which have been found to be impacted by product variety increases to the associated business processes. Table 3 presents the key, variety-influenced business performance literature.

Table 2. Business process performance literature (negative effects).

\begin{tabular}{|c|c|c|}
\hline $\begin{array}{l}\text { Business } \\
\text { process }\end{array}$ & $\begin{array}{l}\text { Business process } \\
\text { activity/cost }\end{array}$ & Related literature \\
\hline \multirow[t]{4}{*}{ Engineering } & Design complexity & Milgate, 2001; Forza and Salvador, 2002; Patel and Jayaram, 2013 \\
\hline & $\mathrm{R} \& \mathrm{D}$ & Yeh and Chu, 1991; Fujita, 2002 \\
\hline & Unit cost of product & $\begin{array}{l}\text { Hayes and Wheelwright, 1984; Anderson, 1995; Krishnan and Gupta, } \\
\text { 2001; Ramdas, 2003; Syam and Bhatnagar, } 2015\end{array}$ \\
\hline & $\begin{array}{l}\text { Engineering/model } \\
\text { change }\end{array}$ & Yeh and Chu, 1991; Fisher et al., 1999; Jiao et al., 2000; Milgate, 2001 \\
\hline \multirow[t]{12}{*}{ Manufacturing } & Quality control & $\begin{array}{l}\text { Banker et al., 1990; Fisher et al., 1995; MacDuffie et al., 1996; Tang } \\
\text { and Yam, 1996; Fisher and Ittner 1999; Sutton, 2001; Patel and } \\
\text { Jayaram, } 2013\end{array}$ \\
\hline & Manufacturing process & $\begin{array}{l}\text { Yeh and Chu, 1991; Anderson, 1995; Fisher and Ittner, 1999; Flynn } \\
\text { and Flynn, 1999; Alford et al., 2000; Forza and Salvador, 2002; } \\
\text { Thonemann and Bradley, 2002; Bayus et al., 2003; Patel and Jayaram, } \\
2013\end{array}$ \\
\hline & Set-up & $\begin{array}{l}\text { Yeh and Chu, 1991; Fisher and Ittner, 1999; Thonemann and } \\
\text { Bradley, } 2002\end{array}$ \\
\hline & Direct labour & $\begin{array}{l}\text { Banker et al., 1990; Fisher et al., 1995; MacDuffie et al., 1996; } \\
\text { Randall and Ulrich, } 2001\end{array}$ \\
\hline & Process variety & Yeh and Chu, 1991; Zhang et al. 2005 \\
\hline & Part variety & Yeh and Chu, 1991; Fisher et al., 1999; Anderson, 2004 \\
\hline & $\begin{array}{l}\text { Manufacturing } \\
\text { complexity }\end{array}$ & $\begin{array}{l}\text { Yeh and Chu, 1991; Fisher and Ittner, 1999; Alford et al., 2000; } \\
\text { ElMaraghy et al., 2005; Hu et al. 2008; Scavarda et al., 2010; Hu et } \\
\text { al., 2011; ElMaraghy et al., 2013; Modrak et al. } 2014\end{array}$ \\
\hline & Supervision effort & $\begin{array}{l}\text { Banker et al. 1990; Yeh and Chu 1991; Fisher et al., 1995; } \\
\text { MacDuffie et al., } 1996\end{array}$ \\
\hline & Scheduling complexity & $\begin{array}{l}\text { Banker et al., 1990; Yeh and Chu, 1991; Fisher et al., 1995; } \\
\text { MacDuffie et al., 1996; Flynn and Flynn, 1999; Vollmann et al., } \\
\text { 2005; Bozarth et al., 2009; Patel and Jayaram, } 2013\end{array}$ \\
\hline & Material & $\begin{array}{l}\text { Fisher et al., 1995; Tang and Yam, 1996; Randall and Ulrich, 2001; } \\
\text { Er and MacCarthry, } 2003\end{array}$ \\
\hline & Overhead & $\begin{array}{l}\text { Hayes and Wheelwright, 1984; Anderson, 1995; Fisher and Ittner, } \\
\text { 1999; Randall and Ulrich, 2001; Forza and Salvador, 2002; Patel and } \\
\text { Jayaram, } 2013\end{array}$ \\
\hline & $\begin{array}{l}\text { Manufacturing lead } \\
\text { time }\end{array}$ & $\begin{array}{l}\text { Thonemann and Bradley, 2002; Er and MacCarthry, 2003; Xia and } \\
\text { Rajagopalan, } 2009\end{array}$ \\
\hline
\end{tabular}




\begin{tabular}{|c|c|c|}
\hline & $\begin{array}{l}\text { Process technology } \\
\text { investment }\end{array}$ & Randall and Ulrich, 2001 \\
\hline \multirow[t]{3}{*}{ Procurement } & Purchasing & Fisher et al., 1995; Randall and Ulrich 2001 \\
\hline & $\begin{array}{l}\text { Order processing } \\
\text { complexity }\end{array}$ & $\begin{array}{l}\text { Carr and Pearson, 2002; Forza and Salvador, 2002; Vollmann et al., } \\
\text { 2005; Zhang et al., 2007; Bozarth et al., } 2009\end{array}$ \\
\hline & $\begin{array}{l}\text { Purchased component / } \\
\text { part variety }\end{array}$ & Fisher et al., 1999; Forza and Salvador, 2002 \\
\hline \multirow[t]{7}{*}{ Logistics } & $\begin{array}{l}\text { Work in-process } \\
\text { inventory }\end{array}$ & $\begin{array}{l}\text { Yeh and Chu, 1991; Martin and Ishii, 1996; Srinivasan and } \\
\text { Viswanathan, } 2010\end{array}$ \\
\hline & $\begin{array}{l}\text { Finished goods } \\
\text { inventory }\end{array}$ & $\begin{array}{l}\text { Yeh and Chu, 1991; Randall and Ulrich, 2001; Forza and Salvador, } \\
\text { 2002; Benjaafar et al., 2004; Syam and Bhatnagar, } 2015\end{array}$ \\
\hline & Total inventory & $\begin{array}{l}\text { Martin and Ishii, 1996; Fisher and Ittner, 1999; Thonemann and } \\
\text { Bradley, 2002; Er and MacCarthry, 2003; Benjaafar et al., 2004; } \\
\text { Patel and Jayaram, 2013; Wan et al., 2014 }\end{array}$ \\
\hline & $\begin{array}{l}\text { Purchased parts } \\
\text { inventory }\end{array}$ & Forza and Salvador, 2001 \\
\hline & Delivery time & $\begin{array}{l}\text { Anderson, 1995; Kotteaku et al., 1995; Fisher and Ittner, 1999; Flynn } \\
\text { and Flynn, 1999; Forza and Salvador, 2002; Zhang et al., } 2007\end{array}$ \\
\hline & $\begin{array}{l}\text { Material } \\
\text { inventory/handling }\end{array}$ & $\begin{array}{l}\text { Abegglen and Stalk, 1985; Yeh and Chu, 1991; Fisher et al., 1995; } \\
\text { Benjaafar et al. 2004; Scavarda et al. } 2010\end{array}$ \\
\hline & Transportation & Lee, 2002; Chopra, 2003; Chopra and Meindl, 2007 \\
\hline Sales & $\begin{array}{l}\text { Demand forecast } \\
\text { uncertainty }\end{array}$ & $\begin{array}{l}\text { Fisher et al., 1995; Whang and Lee, 1998; Randall and Ulrich, 2001; } \\
\text { Er and MacCarthry, 2003; Wan et al., 2012; Wan et al., 2014; Wan } \\
\text { and Sanders, } 2017\end{array}$ \\
\hline
\end{tabular}

Table 3. Business performance literature (positive effects).

\begin{tabular}{ll}
\hline Business performance & \multicolumn{1}{c}{ Related literature } \\
\hline Customer satisfaction & Kekre and Srinivasan, 1990; Yeh and Chu, 1991; Vollmann et al., 2005; Lifang, \\
& 2007; Xia and Rajagopalan 2009; Syam and Bhatnagar 2015 \\
Sales / Market share & Kekre and Srinivasan, 1990; Tang and Yam, 1996; Rajagopalan and \\
& Swaminathan, 2001; Bayus et al. 2003; Otero-Neira et al., 2010; ; Scavarda et \\
& al., 2010; Syam and Bhatnagar, 2015 \\
& Yeh and Chu, 1991; Tang and Yam, 1996; Jiao and Tseng, 1999; Otero-Neira et \\
\hline
\end{tabular}

The fundamental, theoretical grounding of this work concerns the resource-based view (RBV) of the firm which suggests that firms gain and sustain competitive advantage by deploying valuable resources and capabilities (Wenerfelt, 1984; Ray et al., 2004). Extending a product offering, and increasing and satisfying consumer choice can provide a source of competitive advantage. We take particular inspiration from the much-cited work of Ray et al. (2004) who tested resource-based logic at the business process unit of analysis and asserted that "business processes are the mechanisms through which resources and capabilities get exposed to market processes where their ultimate value and ability to generate competitive advantages are realized". The authors also acknowledged that the ability of firms to effectively carry out certain business processes may be limited by the 
effectiveness of the resources and capabilities they control. The RBV perspective directly links process activity to firm performance. The four criteria which often define RBV can be interpreted as: valuable - improve effectiveness or efficiency, rare - not particularly available to others, imperfectly imitable - not easily implemented by others, and nonsubstitutable - not easily replaced. In our study, we also use the fundaments of Porter's work (Porter, 1985) to identify those business unit processes which constitute the value chain of activities which are necessary to produce and deliver a valuable product for a market but with the explicit inclusion of Engineering added to Porter's primary value chain activities of Logistics, Operations and Sales, and Procurement from the support activities. Engineering is necessarily included because of its profound implications for changes in product variety. In this study, Engineering, Manufacturing, Procurement, Logistics, and Sales, represent the principal business process aggregations across the firm's value chain. They are clusters of routines or activities that a firm necessarily develops in order to complete tasks and get things achieved (Porter, 1991). In our research, although we acknowledge different theoretical perspectives, we regard the terms 'routine' and 'activity' to have interchangeable meanings, and select and use the term 'activity' to portray and distinguish between different business processes. Designing products, manufacturing products and procuring components and materials are examples of key business processes. Processing orders, setting-up machines, controlling quality and handling materials are examples of business process activities. In addition, we recognise that the level of customisation moderates the impact of product variety on business process performance (Davila and Wouters, 2007); a high level of customer involvement (i.e. customisation) using an upstream de-coupling point lessens the impact of product variety on business process performance. 


\section{Method and Results}

Mixed-methods research uses a combination of qualitative and quantitative approaches either concurrently or sequentially in order to understand a phenomenon of interest in a single research study. Research that employs a mixed-methods methodology is rare yet mixed methods have the potential to make profound contributions to theory and practice (Venkatesh et al., 2013). For example, Golicic and Davis (2012) found a low incidence of mixed-methods research in supply chain management but also found there to be a significant opportunity to advance the discipline through the application of mixed-methods as such approaches can provide a richer understanding of complex supply chain management phenomena. A key advantage of a mixed-methods design is the ability to address an exploratory and confirmatory question within the same study (Venkatesh et al., 2013; Teddie and Tashakkori, 2009). There are recognised to be four major forms of the mixed-methods approach: (1) triangulation (merging qualitative with quantitative data), (2) embedded (use a qualitative technique in a largely quantitative approach, for example), (3) explanatory (using qualitative data to explain quantitative results), (4) using quantitative data to test and explain a relationship found in qualitative data (Venkatesh et al., 2013).

In this study, we adopt a sequential mixed methods approach where we first undertake an exploratory, qualitative study in order to identify if business processes are affected differently by increases in product variety and then having established an apparent difference, a quantitative study in the form of a survey is undertaken in order to confirm that such a difference does exist and to further research the nature of the difference. The unresearched nature of the phenomenon of interest led to a qualitative lead for the study. The qualitative approach is suitable as a starting point when the context for the research is complex and new (Golicic and Davis, 2012). Qualitative, inductive research allows an initial and detailed understanding of how manufacturers working under different customisation 
regimes set up to deal with product variety changes across their business process value chains. The qualitative study also acts as a preliminary study for in-depth understanding of the concept to set up the more heavily-weighted quantitative study. A sequential approach where the methods have unequal weights has been referred to as an initiation approach (Golicic and Davis, 2012; Teddie and Tashakkori, 2009). Such a design was adopted as it was desirable to have an initial exploration of the subject matter to examine variety versus business process performance directly in the field, propose and confirm business process content analysis and gather evidence to determine the impacts business processes are exposed to when product variety increases. This was followed by a more substantive second phase to further examine the nature and detail of the relationship between process performance and variety increases.

Based on the extant literature concerning the business process implications of product variety increases, a wide range of business process performance variables and costs from a range of different business processes were deemed suitable for analysis in this research. These variables are key to fully understanding the overall process of dealing with product variety from a product manufacturer's perspective and are articulated in tables 2 and 3. In addition, the Lampel and Mintzberg (1996) framework was chosen as the model for customisation management in this research. The principal reasons for this concern its relative simplicity and its wide citation by researchers. The framework highlights the customisation (see Table 1), and hence decoupling point, position for each type. Typically, a make-to-stock (MTS) policy is used upstream of the decoupling point, while a make-toorder (MTO) policy is used downstream. Pure standardisation (PS) concerns the provision of standard products that have pre-defined options and designs. Products are sold commonly to all customers and no distinctions are made between different customers. Typical PS examples include refined chemicals, paper, and electricity and water utilities. Segmented 
standardisation (SS) concerns the provision of standard products with pre-defined options and designs in which customers may customise product packaging, delivery schedules, or delivery location; customisation occurs at the sales and distribution stages. Customers are regarded as aggregated clusters who have no influence over product design or production decisions. SS examples may include medicines and DVDs where final packaging and market location can distinguish the product. Customised standardisation (CS) concerns the provision of various types of products that are assembled to customer order using standard components in which customers are offered a number of pre-defined options; customisation occurs at the assembly stage and fabrication is not customised. This approach is also known as modularisation. Examples include cars, furniture and even fast food items that are configured to order. Tailored customisation (TC) concerns the provision of various types of products that are manufactured to customer order, in which customers are offered a number of pre-defined designs; customisation occurs at the fabrication stage but product design is not customised. Examples may include tailored clothing, toolmaking or a bespoke birthday cake. Pure customisation (PC) concerns the provision of a unique, designed-to-order product, in which customer input is captured at the start of the design process; customisation occurs at the design stage. Personalised jewellery and complex machinery are examples of PC products.

\subsection{The Case Studies}

Case studies were undertaken at four firms where five different product families were identified. Each product family was classified as having pure standardisation (PS), segmented standardisation (SS), customised standardisation (CS), tailored customisation (TC) or pure customisation (PC) characteristics. An initial list of nine firms, chosen to reflect their customisation diversity, was approached and responded to a pre-qualification 
questionnaire from which the four firms and five of their product families were selected in order to take part in the study. Each family, identified from a series of questions, belonged separately to one of the customisation types: PS, SS, CS, TC or PC. Each firm was also wellestablished and, in each, the chosen product families had been exposed to product variety increases.

The case studies were undertaken in order to attempt to understand how different business processes cope with an increase in product variety. At each firm, between three and five semi-structured interviews were conducted with different staff. The interviews formed one third of a triangulation-based approach to knowledge acquisition which also included direct observation of the sales, engineering, manufacturing, supply and distribution systems and a review of relevant documentation including market analyses, business improvement strategies, annual reports and manufacturing and supply chain performance analyses. Table 4 summarises the key characteristics of the case study environments.

Table 4. Summary of case study characteristics.

\begin{tabular}{cllll}
\hline Identifier & Lampel \& Mintzberg Class & Product Family & Firm Size & $\begin{array}{c}\text { Focus of product variety } \\
\text { increase }\end{array}$ \\
\hline C1 & Pure standardisation (PS) & Processed meat & Small & $\begin{array}{l}\text { New ingredient added to a } \\
\text { standard product. }\end{array}$ \\
C2 & $\begin{array}{l}\text { Segmented standardisation } \\
\text { (SS) }\end{array}$ & $\begin{array}{l}\text { Liquid reference } \\
\text { material (standard) }\end{array}$ & Small & $\begin{array}{l}\text { New packaging formulation } \\
\text { and delivery location. }\end{array}$ \\
C3 & $\begin{array}{l}\text { Customised standardisation } \\
\text { (CS) }\end{array}$ & $\begin{array}{l}\text { Electronic } \\
\text { instrument }\end{array}$ & Large & New product option. \\
C4 & Tailored customisation (TC) & $\begin{array}{l}\text { Precision engineered } \\
\text { assembly } \\
\text { Liquid reference } \\
\text { material (unique) }\end{array}$ & Small & $\begin{array}{l}\text { New product derived from } \\
\text { existing product design. }\end{array}$ \\
C5 & Pure customisation (PC) & Small & Unique product \\
\hline
\end{tabular}

The $\mathrm{C} 1$ firm is a small, family-owned producer of cooked-meat products which started trading in the 1940s. The product chosen, a processed meat, is an example of a pure standardised (PS) product. It is well-established and produced in large volume to a standard recipe. The $\mathrm{C} 2$ and $\mathrm{C} 5$ firm is a small, high-tech manufacturer of reference material and 
liquid standards used to test product specification conformance in the pharmaceuticals, chemicals and beverages industries. The firm, established in 1994, has grown quickly, and has a wide product range and competes internationally. Two products were chosen. One, $\mathrm{C} 2$, concerns segmented standardisation (SS) and belongs to a family of standard reference products used to measure viscosity which are customised only in terms of packaging, delivery location and the timing of customer call-off. The second, C5, is an example of pure customisation (PC) and relates to the firm's capability to engineer-to-order, and design and produce a unique reference product. C3 is a global manufacturer of electronic instruments and electromechanical devices with over 150 manufacturing facilities worldwide. The chosen factory automation product is mass customised and assembled to customer order with pre-defined options. It is an example of a customised standard (CS). C4 is a precision engineering job shop with over 30 years of trading experience. The chosen product is a subcontracted precision engineering assembly for the petrochemical industry. The product is an example of tailored customisation (TC). It is manufactured to customer order but derived from a standard design.

In each case, the interviews were conducted in order to establish the impact of an increase in product variety on Engineering, Manufacturing, Procurement, Logistics, and Sales business process activities, and identify and establish the effectiveness of implemented variety management capabilities. Staff from these different areas with responsibility and experience of their management were interviewed and, in addition to eliciting information concerning the challenges, goals and operational activities of each major business process, the implications of a product variety increase were explored. In each case, and for each major business process, this exploration of a product variety impact was undertaken by prompting the interviewee to recount the procedural and resource effects of a typical increase in the selected product family range and encouraging each interviewee to provide examples of how 
the administrative and cost burdens were manifested and which business process activities were contributory. An increase was regarded as a typical extension to the range of the selected product family as illustrated by an example of a similar, past increase. This is an external-facing, 'within-product' variety increase. Interviewees (in some cases, certain interviewees had responsibility for, and knowledge and experience of more than one business process) were also asked to quantitatively estimate the impact of the change on the business process and the business process activities brought about as a consequence of the variety increase. They also provided information on how variety-inducing problems are mitigated. Inconsistencies were examined between interviewees and supporting documentation such as recipe and bill-of-material changes, raw material and component procurement histories, packaging design changes, and routing and process plan changes were examined.

In $\mathrm{C} 1$, the case concerned a new ingredient added to an existing product to provide a new cooked meat variant. The ingredient was significant in enhancing the product family range and provided a novel and newly-marketable processed meat product. This new product was then produced on a semi-continuous basis. Demand forecast uncertainty, ingredient cost and manufacturing complexity were particularly impacted by the product variety change. In $\mathrm{C} 2$, the increase was initiated by the acquisition of a new customer for an existing product resulting in a new delivery destination and packaging formulation for the product. Forecast uncertainty, packaging set-up and cost (recognised as a manufacturing cost), procurement of the packaging materials and transportation costs were prominent. In $\mathrm{C} 3$, the increase concerned a new optional offering for an existing product. A variety increase resulted in a range of impactful cost and resource burden increases including demand forecast uncertainty, production set-up and changeover costs, direct labour cost, scheduling complexity and work-in-process inventories. In $\mathrm{C} 4$, a new product derived from an existing 
design resulted in additional burdens associated with engineering design modifications, manufacturing and scheduling complexity increases and additional procurement requirements. In $\mathrm{C} 5$, a new reference material was developed. In C5 only, does the variety increase relate to a completely new and unique product offering. The complex chemistry associated with this resulted in a considerable research and development (engineering) effort. Table 5 presents an attempt to summarise the additional administrative and cost burdens of a variety increase on each business process. The figures represent a simple numerical translation of the aggregation of the impacts on the various business processes expressed in percentage terms. Hence, 'up to 10' indicates an additional increase of up to $10 \%$ in resourcing and administration costs. For each case, at least three people were interviewed and the figures in table 5 represent a convergence of their views.

Table 5. Variety impacts on business processes.

\begin{tabular}{|c|c|c|c|c|c|c|c|}
\hline & Case Study & $\mathrm{C} 1$ & $\mathrm{C} 2$ & $\mathrm{C} 3$ & $\mathrm{C} 4$ & C5 & Impact \\
\hline & ustomisation Type & PS & SS & CS & $\mathrm{TC}$ & PC & Mean \\
\hline \multirow{6}{*}{$\begin{array}{l}\text { Business } \\
\text { Process } \\
\text { Impact (\%) }\end{array}$} & Engineering & Up to 10 & Minimal & Up to 10 & Up to 10 & Up to 10 & $8 \%$ \\
\hline & Manufacturing & Up to 10 & Up to 10 & Up to 10 & Up to 10 & Minimal & $8 \%$ \\
\hline & Procurement & Up to 10 & Up to 10 & Up to 10 & Up to 10 & Minimal & $8 \%$ \\
\hline & Logistics & Up to 10 & Up to 10 & Minimal & Minimal & Minimal & $4 \%$ \\
\hline & Sales & Up to 25 & Up to 20 & Up to 10 & Minimal & Minimal & $11 \%$ \\
\hline & Mean & $13 \%$ & $8 \%$ & $8 \%$ & $4 \%$ & $2 \%$ & $\%$ \\
\hline
\end{tabular}

Table 5 suggests an increase in product variety impacts business processes differently with Sales being most impacted and Logistics least, with impact being most pronounced in PS environments and least in PC. In addition, strategies adopted and their relative effectiveness in dealing with variety changes were also established in each of the cases. In order to reveal such information, the same interviewees were asked to identify the capabilities gained in facilitating the management of variety and consequently mitigating the effects of variety increases. Table 6 illustrates those capabilities identified in their firms 
and their perceived effectiveness ranking. The ranking is a convergence of the views of the respondents.

Table 6. Variety-management capabilities.

\begin{tabular}{|c|c|c|c|c|c|}
\hline Case Study & $\mathrm{C} 1$ & $\mathrm{C} 2$ & $\mathrm{C} 3$ & $\mathrm{C} 4$ & C5 \\
\hline Customisation Type & PS & SS & $\mathrm{CS}$ & $\mathrm{TC}$ & $\mathrm{PC}$ \\
\hline \multirow{4}{*}{$\begin{array}{l}\text { Strategy used \& } \\
\text { effectiveness ranking } \\
\text { (highest to lowest) }\end{array}$} & $\begin{array}{c}\text { Standard } \\
\text { ingredients }\end{array}$ & $\begin{array}{l}\text { Modular } \\
\text { recipe }\end{array}$ & $\begin{array}{c}\text { Modular } \\
\text { design }\end{array}$ & $\begin{array}{c}\text { Process } \\
\text { standardisation }\end{array}$ & $\begin{array}{c}\text { Part } \\
\text { standardisation }\end{array}$ \\
\hline & $\begin{array}{c}\text { Process } \\
\text { standardisation }\end{array}$ & $\begin{array}{c}\text { Process } \\
\text { standardisation }\end{array}$ & $\begin{array}{c}\text { Cellular } \\
\text { manufacturing }\end{array}$ & $\begin{array}{c}\text { Modular } \\
\text { design }\end{array}$ & $\begin{array}{c}\text { Process } \\
\text { standardisation }\end{array}$ \\
\hline & $\begin{array}{c}\text { Flexible } \\
\text { manufacturing }\end{array}$ & & $\begin{array}{c}\text { Flexible } \\
\text { manufacturing }\end{array}$ & $\begin{array}{c}\text { Flexible } \\
\text { manufacturing }\end{array}$ & \\
\hline & & & $\begin{array}{c}\text { Process } \\
\text { standardisation }\end{array}$ & $\begin{array}{c}\text { Cellular } \\
\text { manufacturing }\end{array}$ & \\
\hline
\end{tabular}

\subsection{The Survey}

The survey was undertaken in order to corroborate, or otherwise, the findings from the case studies and to further explore the impact of a product variety increase on business process performance and explain the reasons for such differences. A questionnaire composed of 31 questions concerning the impact of product variety on business processes (see Appendix) and 2 questions related to customisation and product variety were sent to companies identified as manufacturers based on their standard industrial classification (SIC) code in the UK. The survey package included a covering letter and return stamped envelope. From 1,500 questionnaires sent by post, 162 companies responded to the survey, yielding a 10.8\% overall response rate, which was considered acceptable (Frohlich 2002). Questionnaires were returned by CEOs (31\%), directors (41\%), and managers (28\%). 6.1\% of the firms had fewer than 50 employees (small), 52.4\% had 50-250 employees (medium) and $41.5 \%$ had more than 250 employees (large). Respondents were from a wide range of manufacturing sectors. Table 7 represents the industry types of the survey respondents. Innovative products found in industries such as electrical components, transportation and 
clothing typically displayed higher levels of product variety than functional products such as chemicals, wood and paper.

Table 7. Survey respondents.

\begin{tabular}{lcccccccc}
\hline Manufacturing industry type & PS & SS & CS & TC & PC & $\begin{array}{c}\text { Variety } \\
\text { Mean }\end{array}$ & Total & Valid \% \\
\hline Food, beverage, tobacco & 1 & 3 & 4 & 4 & 3 & 4.1 & 15 & 8.0 \\
Wood and furniture & 4 & 3 & 2 & 3 & 6 & 3.6 & 18 & 9.9 \\
Chemical materials/products & 2 & 4 & 0 & 2 & 1 & 3.3 & 9 & 7.1 \\
Non-metal mineral products & 1 & 0 & 1 & 3 & 1 & 4.5 & 6 & 4.7 \\
Fabricated metal products & 2 & 1 & 5 & 9 & 4 & 3.8 & 21 & 13.7 \\
Computer \& comms products & 0 & 0 & 2 & 4 & 0 & 3.8 & 6 & 4.2 \\
Electrical parts \& components & 1 & 3 & 5 & 5 & 3 & 3.9 & 17 & 9.0 \\
Electrical machinery \& equipment & 1 & 3 & 3 & 7 & 1 & 3.9 & 15 & 8.5 \\
Transport equipment & 0 & 2 & 8 & 4 & 2 & 4.3 & 16 & 10.8 \\
Textiles and leather & 0 & 0 & 1 & 1 & 2 & 4.3 & 4 & 2.4 \\
Paper products & 1 & 0 & 2 & 0 & 0 & 3.7 & 3 & 1.4 \\
Machinery and equipment & 2 & 0 & 5 & 5 & 4 & 3.8 & 16 & 10.8 \\
Basic metal products & 1 & 0 & 0 & 0 & 2 & 4.0 & 3 & 2.4 \\
Clothing and footwear & 0 & 1 & 0 & 3 & 1 & 4.2 & 5 & 2.4 \\
Other & 0 & 3 & 2 & 1 & 2 & 3.9 & 8 & 4.7 \\
Total & 16 & 23 & 40 & 51 & 32 & 3.9 & 162 & $100 \%$ \\
\hline
\end{tabular}

Non-response bias is regarded as a significant source of error in survey-based research (Dillman, 2007). Non-response bias occurs when those who participated in the survey differ significantly from those who did not in terms of key characteristics of interest to the study. This study followed a simple method suggested by Gerbing and Anderson (1988) to check the existence of non-response bias. The study sample was investigated to determine whether non-respondent manufacturers differed significantly from those responding in terms of key characteristics (for example, sales and number of employees). The comparison revealed that the sample did not suggest the presence of non-response bias.

Each manufacturer was classified as having a degree of product customisation that corresponded to PS, SS, CS, TC or PC. Positive performance, derived from a product variety increase, was examined via a consideration of competitive advantage, customer satisfaction, 
sales and market share. In addition, respondents were asked to indicate the relative impact of product variety increases on each business process activity using a 1 to 10 scale, in which 1 indicates minimal effect and 10 indicates a very high material effect on the business process activity (see Appendix). Thus, a product variety increase was considered in terms of its impact on a business process activity relative to the state of the business process activity prior to the variety increase, and also in terms of the difference between the impacts perceived to be caused by the variety increase on each of the business process activities. As proposed by Matell and Jacoby (1972), the purpose of this type of scale is to allow respondents to express a specific choice rather than choose intermediate positions. Both the cost and non-cost-related negative aspects of business process performance were considered. Cost-related items comprised $\mathrm{R} \& \mathrm{D}$ cost, the unit cost of the product, engineering design/change cost, manufacturing process cost, set-up cost, direct labour cost, material cost, overhead cost, process technology investment cost, purchasing cost, inventory cost, material handling cost and transportation cost. Non-cost-related negative performance comprised demand forecast uncertainty, scheduling complexity, design complexity, manufacturing complexity, part variety, supervision effort, quality control, manufacturing lead time, process variety, work-in-process inventory, finished goods inventory, purchased component variety, purchased component inventory, delivery time and order processing. We assumed all impacts are negative with respect to costs and non-costs, and positive with respect to customer satisfaction, sales / market share and competitive advantage. Notably, each item was drawn from previously published research, which supports the existence of content validity. The impact of a product variety increase comprises several components and not all of which can be precisely measured. For example, scheduling complexity is difficult to measure as is set-up cost but there may be a recognition that it consists of labour resource, labour time and material used. It is therefore easier to regard it relatively rather than 
absolutely. This is the case with many of the business process activity costs. Also, the purpose of the questionnaire is to allow for a relative analysis of the impact of product variety increases on business process activities not on absolute performance.

Product variety was measured as a combination of fundamental (number of different core models and designs for the manufacturer's products), intermediate (number of different technical options and sizes dependent on core design) and peripheral variety (number of particular options and accessories independent of core design) using a 5-point scale (1=1$5,2=6-10,3=11-15,4=16-20,5=$ above 20 ) based on the core product family (MacDuffie et al., 1996).

The ANOVA results (Table 8) indicate that statistically significant differences exist among the different customisation types $(\mathrm{p}=0.01)$. PS is impacted upon the most by an increase in product variety, followed by SS, CS, TC and PC. In addition, in order to compare the existing level of product variety according to level of customisation, an ANOVA was conducted for using the three dimensions of variety (fundamental, intermediate and peripheral - derived from section A2 in the survey questionnaire) in relation to each type of customisation (see Table 8). The results show significant statistical differences at the 0.1 levels. Typically, high-customisation types are expected to display greater product variety than low-customisation types with a general increase in variety across the PS to PC sequence. However, unexpectedly, TC displayed the highest level of product variety followed by CS, PC, PS and SS, which explains the minor correlations $(r=0.15)$ between variety level and customisation. 
Table 8. Variety level and the impact of a variety increase on business process performance across customisation types.

\begin{tabular}{lccccccccc}
\hline & \multicolumn{7}{c}{ Mean } & & \\
\cline { 2 - 7 } Performance & $\begin{array}{c}\text { PS } \\
(\mathrm{n}=16)\end{array}$ & $\begin{array}{c}\mathrm{SS} \\
(\mathrm{n}=23)\end{array}$ & $\begin{array}{c}\mathrm{CS} \\
(\mathrm{n}=40)\end{array}$ & $\begin{array}{c}\mathrm{TC} \\
(\mathrm{n}=51)\end{array}$ & $\begin{array}{c}\mathrm{PC} \\
(\mathrm{n}=32)\end{array}$ & $\begin{array}{c}\text { Total } \\
(\mathrm{n}=162)\end{array}$ & $\mathrm{F}$ & Sig \\
\hline Variety Impact & 5.35 & 4.75 & 4.36 & 4.16 & 3.43 & 4.27 & $3.443 * *$ & .010 \\
\hline Variety Level & 3.54 & 3.46 & 3.92 & 4.23 & 3.88 & 3.67 & $2.319 *$ & .059 \\
\hline *represents significant level $\mathrm{p}<0.1, * * * \mathrm{P}<0.001$ & & & & & &
\end{tabular}

Then, an ANOVA was undertaken once more to examine the impact of increased product variety on each process variable. The results are displayed in Tables 9, 10 and 11. Business processes are typically impacted most by an increase in product variety in PS environments followed by SS, CS, TC and PC. However, process variety (CS < TC), purchasing cost (CS $<\mathrm{TC}$ ), purchased component variety $(\mathrm{SS}<\mathrm{CS})$ and delivery time $(\mathrm{SS}<\mathrm{CS})$ displayed a different order. Customer satisfaction, market share (SS < CS) and competitive advantage were found to be significant positive performance items. The top five highest cost and noncost negative performance variables impacted by increased variety, by mean value were: demand forecast uncertainty (5.15), scheduling complexity (5.07), design complexity (4.86), $R \& D$ cost (4.76) and engineering design change cost (4.69). The top five by maximum value were: demand forecast uncertainty (6.88 (PS)), scheduling complexity (6.13 (PS)), material cost (6.06 (PS)), manufacturing process cost (5.94 (PS)) and delivery time (5.81 (PS)). The lowest five, and therefore, least affected by a product variety increase were, by mean value: order processing (3.65), transportation cost (3.75), material handling cost (3.80), delivery time (3.89) and purchased component inventory (3.90). The lowest five by minimum value were: transportation cost $(2.81(\mathrm{PC}))$, order processing $(2.84(\mathrm{PC}))$, process variety $(3.00$ (PC)), purchased component variety (3.06 (PC), and part variety and set-up cost (both 3.09 (PC)). In addition, six items showed differences across the PS to PC sequence that were significant at $\mathrm{p}<0.01$, and six items showed differences significant at $\mathrm{p}<0.05$. These items 
were as follows: the unit cost of each product, manufacturing process cost, process variety, part variety, manufacturing complexity, material cost, manufacturing lead time, purchasing cost, purchased components, work-in-process inventory, delivery time and demand forecast uncertainty. Differences between the customisation types are incremental hence statistical significance for cross-sequence characteristics was found for relatively few performance variables.

Table 9. Variety impact on cost performance variables.

\begin{tabular}{|c|c|c|c|c|c|c|c|c|}
\hline \multirow[b]{2}{*}{ Business process variable } & \multicolumn{5}{|c|}{ Customisation type } & \multirow[b]{2}{*}{$\begin{array}{c}\text { Mean } \\
(n=162)\end{array}$} & \multirow[b]{2}{*}{$\mathrm{F}$} & \multirow[b]{2}{*}{ Sig } \\
\hline & $\begin{array}{c}\text { PS } \\
(n=16)\end{array}$ & $\begin{array}{c}\mathrm{SS} \\
(\mathrm{n}=23)\end{array}$ & $\begin{array}{c}\mathrm{CS} \\
(\mathrm{n}=40)\end{array}$ & $\begin{array}{c}\text { TC } \\
(n=51)\end{array}$ & $\begin{array}{c}\text { PC } \\
(n=32)\end{array}$ & & & \\
\hline $\mathrm{R} \& \mathrm{D}$ cost & 4.88 & 5.35 & 4.45 & 4.82 & 4.56 & 4.76 & .430 & .787 \\
\hline Unit cost of product & 5.63 & 4.57 & 4.53 & 4.06 & 3.19 & 4.23 & $3.529 * *$ & .009 \\
\hline Engineering design change cost & 5.31 & 5.13 & 4.88 & 4.67 & 3.84 & 4.69 & 1.451 & .220 \\
\hline Manufacturing process cost & 5.94 & 5.00 & 4.23 & 3.94 & 3.31 & 4.23 & $4.702 * * *$ & .001 \\
\hline Set-up cost & 4.75 & 4.70 & 4.13 & 4.08 & 3.09 & 4.05 & 1.980 & .100 \\
\hline Direct labour cost & 4.81 & 4.39 & 3.45 & 3.63 & 3.78 & 3.84 & .760 & .553 \\
\hline Material cost & 6.06 & 5.09 & 4.58 & 4.14 & 3.28 & 4.40 & $4.256 * *$ & .003 \\
\hline Overhead cost & 4.88 & 4.48 & 4.08 & 3.86 & 3.31 & 3.99 & 1.432 & .226 \\
\hline Process technology investment cost & 5.13 & 4.83 & 3.88 & 4.78 & 3.31 & 4.31 & $2.315+$ & .060 \\
\hline Purchasing cost & 5.75 & 4.43 & 4.35 & 4.75 & 3.28 & 4.41 & $2.619^{*}$ & .037 \\
\hline Inventory cost & 5.63 & 4.48 & 4.18 & 4.00 & 3.75 & 4.22 & 1.655 & .163 \\
\hline Material handling cost & 4.94 & 3.91 & 3.80 & 3.73 & 3.25 & 3.80 & 1.339 & .258 \\
\hline Transportation cost & 4.81 & 4.22 & 3.95 & 3.65 & 2.81 & 3.75 & $2.274+$ & .064 \\
\hline
\end{tabular}

+ represents significant level $\mathrm{p}<0.1, *$ represents significant level $\mathrm{p}<0.05, * * \mathrm{p}<0.01, * * * \mathrm{p}<0.001$ 
Table 10. Variety impact on non-cost negative performance variables.

\begin{tabular}{|c|c|c|c|c|c|c|c|c|}
\hline \multirow{2}{*}{ Item } & \multicolumn{4}{|c|}{ Customisation type } & \multirow[b]{2}{*}{$\begin{array}{c}\mathrm{PC} \\
(\mathrm{n}=32)\end{array}$} & \multirow[b]{2}{*}{$\begin{array}{c}\text { Mean } \\
(\mathrm{n}=162)\end{array}$} & \multirow[b]{2}{*}{$\mathrm{F}$} & \multirow[b]{2}{*}{ Sig } \\
\hline & $\begin{array}{c}\text { PS } \\
(\mathrm{n}=16)\end{array}$ & $\underset{(n=23)}{S S}$ & $\begin{array}{c}\mathrm{CS} \\
(\mathrm{n}=40)\end{array}$ & $\begin{array}{c}\mathrm{TC} \\
(\mathrm{n}=51)\end{array}$ & & & & \\
\hline Design complexity & 5.19 & 5.13 & 5.03 & 4.84 & 4.31 & 4.86 & .476 & .753 \\
\hline Quality control & 4.75 & 4.70 & 4.75 & 4.12 & 3.25 & 4.25 & 1.937 & .107 \\
\hline Process variety & 4.94 & 4.91 & 4.13 & 4.33 & 3.00 & 4.16 & $3.101 *$ & .017 \\
\hline Part variety & 5.50 & 5.09 & 4.63 & 4.51 & 3.09 & 4.44 & $3.527 * *$ & .009 \\
\hline Manufacturing complexity & 5.50 & 5.87 & 4.63 & 4.25 & 3.84 & 4.62 & $2.699^{*}$ & .033 \\
\hline Supervision effort & 5.06 & 5.30 & 4.60 & 4.31 & 3.47 & 4.43 & 1.924 & .109 \\
\hline Scheduling complexity & 6.13 & 5.52 & 5.48 & 4.67 & 4.34 & 5.07 & 1.813 & .129 \\
\hline Manufacturing lead time & 5.25 & 5.22 & 4.48 & 4.00 & 3.13 & 4.24 & $3.359^{*}$ & .011 \\
\hline Order processing & 4.81 & 3.70 & 3.90 & 3.57 & 2.84 & 3.65 & 1.959 & .103 \\
\hline Purchased component variety & 5.44 & 4.04 & 4.10 & 3.94 & 3.06 & 3.97 & $2.427^{*}$ & .050 \\
\hline Work-in-process inventory & 5.44 & 4.74 & 4.30 & 3.86 & 3.19 & 4.12 & $2.583^{*}$ & .039 \\
\hline Finished goods inventory & 5.56 & 4.09 & 4.18 & 3.86 & 3.22 & 4.01 & $2.180+$ & .074 \\
\hline Purchased component inventory & 5.19 & 4.04 & 4.13 & 3.73 & 3.16 & 3.90 & $2.114+$ & .082 \\
\hline Delivery time & 5.81 & 3.87 & 4.25 & 3.45 & 3.19 & 3.89 & $3.588^{* *}$ & .008 \\
\hline Demand forecast uncertainty & 6.88 & 6.13 & 5.05 & 4.82 & 4.25 & 5.15 & $3.622 * *$ & .007 \\
\hline
\end{tabular}

+ represents significant level $\mathrm{p}<0.1, *$ represents significant level $\mathrm{p}<0.05, * * \mathrm{p}<0.01, * * * \mathrm{p}<0.001$

Table 11. Variety impact on positive variables.

\begin{tabular}{lccccccccc}
\hline \multicolumn{1}{c}{ Item } & \multicolumn{9}{c}{ Customisation type } \\
& $\begin{array}{l}\text { PS } \\
(\mathrm{n}=16)\end{array}$ & $\begin{array}{c}\mathrm{SS} \\
(\mathrm{n}=23)\end{array}$ & $\begin{array}{c}\mathrm{CS} \\
(\mathrm{n}=40)\end{array}$ & $\begin{array}{c}\mathrm{TC} \\
(\mathrm{n}=51)\end{array}$ & $\begin{array}{c}\mathrm{PC} \\
(\mathrm{n}=32)\end{array}$ & $\begin{array}{c}\text { Total } \\
(\mathrm{n}=162)\end{array}$ & $\mathrm{F}$ & $\mathrm{Sig}$ \\
\hline Customer satisfaction & 6.25 & 5.30 & 5.30 & 4.75 & 3.78 & 4.92 & $2.685^{*}$ & .033 \\
Sales / Market share & 6.13 & 5.09 & 5.18 & 4.57 & 3.78 & 4.79 & $2.666^{*}$ & .034 \\
Competitive advantage & 6.38 & 6.00 & 5.70 & 5.10 & 4.13 & 5.31 & $3.208^{*}$ & .015 \\
\hline
\end{tabular}

+ represents significant level $\mathrm{p}<0.1$, * represents significant level $\mathrm{p}<0.05, * * \mathrm{p}<0.01, * * * \mathrm{p}<0.001$

Table 12 presents the correlation between level of customisation and the impact on aggregated business processes. The negative correlation confirms that higher customisation (1=PS and $5=\mathrm{PC})$ environments are impacted less by an increase in product variety. 
Table 12. Level of customisation - business process impact correlation matrix

\begin{tabular}{|c|c|c|c|c|c|c|c|}
\hline & Variety Impact / Customisation & 1 & 2 & 3 & 4 & 5 & 6 \\
\hline 1 & Level of customisation & 1 & & & & & \\
\hline 2 & Impact on engineering processes & $-.169 *$ & 1 & & & & \\
\hline 3 & Impact on manufacturing processes & $-.283^{* *}$ & $.765^{* *}$ & 1 & & & \\
\hline 4 & Impact on procurement processes & $-.218 * *$ & $.579 * *$ & $.774 * *$ & 1 & & \\
\hline 5 & Impact on logistics processes & $-.249 * *$ & $.681 * *$ & $.784 * *$ & $.781^{* *}$ & 1 & \\
\hline 6 & Impact on sales processes & $-.281 * *$ & $.475^{* *}$ & $.579 * *$ & $.619 * *$ & $.659 * *$ & 1 \\
\hline
\end{tabular}

* represents significant level $\mathrm{p}<0.05, * * \mathrm{p}<0.01$

In order to examine the impact differences of product variety on business processes, an ANOVA test was conducted across the PS-PC sequence. The Manufacturing, Procurement, Logistics and Sales processes displayed significant differences. In addition, Cronbach's alpha for each (Engineering $=0.866$, Manufacturing $=0.945$, Purchasing $=0.883$ and Logistics $=0.944)$ was above 0.7 , which reveals acceptable reliability. The average impact of an increase in product variety on each of the different business processes was found to be as follows: Sales $(\mathrm{m}=5.15)$, Engineering $(\mathrm{m}=4.62)$, Manufacturing $(\mathrm{m}=4.32)$, Procurement $(\mathrm{m}=4.01)$, and Logistics $(\mathrm{m}=3.96)$ (see Table 13). Figure 1 illustrates the impact of a product variety increases across the PS-PC sequence according to business process.

Table 13. Variety impact on each business process.

\begin{tabular}{|c|c|c|c|c|}
\hline \multirow{2}{*}{ Business process impact } & Mean & \multirow[b]{2}{*}{$\mathrm{SD}$} & \multirow[b]{2}{*}{ F-value } & \multirow[b]{2}{*}{ Sig } \\
\hline & Total $(\mathrm{N}=162)$ & & & \\
\hline Engineering ( $\alpha=0.866)$ & 4.63 & 2.18 & 1.282 & .280 \\
\hline Manufacturing $(\alpha=0.945)$ & 4.32 & 1.96 & $3.729 * *$ & .006 \\
\hline Procurement $(\alpha=0.883)$ & 4.01 & 2.32 & $2.789 *$ & .028 \\
\hline Logistics $(\alpha=0.866)$ & 3.96 & 2.15 & $-2.970 *$ & .021 \\
\hline Sales $(\alpha=0.094)$ & 5.15 & 2.73 & $-3.622 * *$ & .007 \\
\hline
\end{tabular}

$*$ represents significant level $\mathrm{p}<0.05, * * \mathrm{p}<0.01, * * * \mathrm{P}<0.001$ 


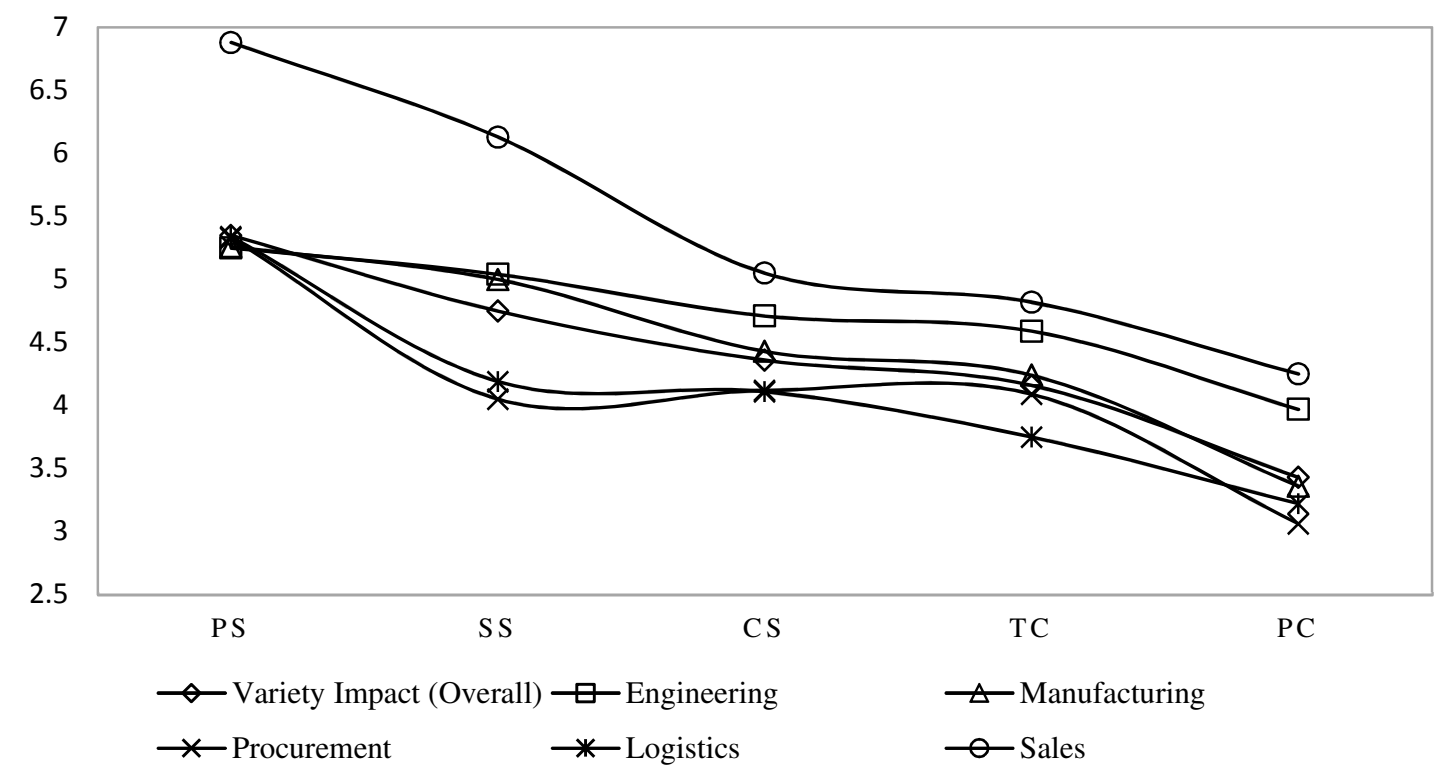

Figure 1. Variety impact by business process across the PS-PC sequence.

\section{Discussion}

The work set out to explore and explain the impact of variety increases on business process activities and performance taking into account the moderating effects of product customisation. In addition, we also set out to identify those business process activities that are impacted most and least by increases in product variety, and the capabilities acquired in mitigating variety effects.

The case studies allowed a detailed investigation of product variety increases to be undertaken within firms possessing different customisation profiles. Sales demonstrated the highest impact followed by Engineering, Manufacturing, Procurement which demonstrated similar levels of impact, and then Logistics. The results of the survey demonstrated that when product variety is increased, the overall impact is highest, and, therefore, most adverse in PS environments followed in turn by SS, CS, TC and PC environments. Similarly, impact is highest in business processes in PS environments followed by those in SS, CS, TC and PC environments. The adverse impact of increased product variety softened across the PS 
to PC sequence in both the case studies and survey. This is attributable to an increase in the business process flexibility and ability to accommodate product change in the more customised types, characteristics which are typically absent in the more standardised types which tend to be relatively more inert and rigid. More highly-customised types typically utilise modularisation and a more upstream decoupling point. On the downstream side of the decoupling point is a more variable demand profile with a large variety of products, and upstream from the decoupling point the demand is smoothed with the variety reduced (Naylor et al., 1999). A high level of customisation using an upstream decoupling point is expected to have less impact on business process performance than low customisation when product variety is increased.

In addition, overall impact differs according to business process. As had been suggested in the cases studies, the survey found consistently higher effects experienced by Sales processes followed by Engineering, Manufacturing, Procurement and Logistics. However, also revealing are the business process activity analyses from the survey. Demand forecast uncertainty was found to be the most impacted process variable in PS and SS environments. In CS environments, it was 'out-impacted' only by scheduling complexity; in TC environments, by design complexity, and in PC environments by scheduling complexity, design complexity and R \& D cost. This suggests that demand forecasting is the most vulnerable business process activity when product variety is increased. However, it was notable that case study respondents did not refer to any acquired capabilities or varietymitigating approaches which would address the challenges associated with forecasting (see Table 6). It is likely that variety-mitigating capabilities' development is not giving due consideration to forecasting as a vulnerable activity when variety is increased. Returning to a key theoretical frame: Ray et al. (2004) recognised that resources and capabilities that are not turned into business activities and processes cannot have a positive impact on a firm's 
performance. Also, the effectiveness of business processes and activities are limited by their acquired capabilities. From our study, managers in manufacturing environments need to be more mindful of the resilience of their forecasting systems when exposed to a variety increase. This advice is pertinent even in environments with upstream decoupling points where demand forecasts are used for resource and material planning rather than finishedgoods inventory provision.

Also, prominently vulnerable to a variety increase is scheduling complexity. The competition for production resource and the ability to schedule efficiently are a real concern for manufacturers when product variety is increased. Design complexity, R \& D cost, engineering design change cost, material cost, manufacturing process cost and delivery time are also conspicuous priorities for manufacturers when confronted with a variety increase. Case evidence suggests (table 6) that some mitigation capabilities do focus on reducing the resource burden and costs for such issues but further attention is necessary. Conversely, transportation, purchase order processing and material handling are business process activities impacted least by a product variety increase suggesting they are sufficiently robust and predicated on economies of scale to be relatively unaffected by increases in product variety.

In addition, it should be noted that the PS to PC sequence was found to be a convenient means for assigning customisation / standardisation profiles to each of the manufacturing respondents, and general trends across the PS to PC sequence did follow the expected changes in characteristics and behaviours across the sequence. The sequence is a robust and reliable form of classification. One exception to the trend pattern concerned the fundamental, intermediate and peripheral variety differences across the customisation types where TC rather than the expected PC environments were found to be the most product-prolific. One possible explanation for this concerns the customisation capability of the PC environments 
not always being utilised whereas the customisation capability of TC environments may be more consistently fully utilised.

Also, it was found that customer satisfaction, sales and market share, and competitive advantage could be positively influenced most by a product variety increase in lowcustomisation environments with the highest potential for business improvement in PS environments. This indicates that despite low-customisation environments being most adversely impacted by product variety increases they are also the environments that can potentially benefit most.

The mixed-methods approach provided a more holistic understanding than a single qualitative or quantitative approach could have done on how product variety increases influence business processes. The perspectives were generally complementary rather than contradictory. The case studies suggested a differential effect across the value chain of business processes and helped define the content of the survey. The cases also provided a deep understanding of how variety effects are manifested and mitigated against. The survey provided corroboration of the case study findings and led to more explicit and generalisable conclusions concerning the relationship between product variety, customisation and business process performance. Overall, combining the cases and survey provided a deeper insight into the subject matter and greater confidence in the results.

\section{Conclusions, limitations and recommendations for future work}

Typically, variety impacts have been studied at the firm or single business process level. However, we deviated from previous studies and, informed by value chain and resourcebased logic, we examined the simultaneous and relative impact of product variety on the performance of business processes via a series of case studies and a survey of 162 manufacturing facilities. Each facility was classified as one of five customisation types 
which provided a sequence across which performance trends could be assessed. The adverse impact of increased product variety was found to diminish across the sequence from highly standardised to highly-customised types. In addition, demand forecasting was found to be impacted the most by an increase in product variety, with scheduling complexity, material cost, manufacturing process cost, $\mathrm{R} \& \mathrm{D}$ cost and design complexity exhibiting a high level of adverse impact. Capabilities to support these process management activities and costs can be neglected when making decisions about extending variety but these activities are the causal factors that explain how business performance is affected by a product variety increase. Conversely, transportation and material handling costs, and purchase order processing were found to be impacted least by an increase in product variety. The findings support the view of Ray et al (2004) who suggested that the differential effectiveness of business processes depends on the capabilities a firm possesses and business process performance can be limited by a lack of acquired capabilities. Managers should be mindful of those activities which are likely to contribute most to business under-performance and be the most obdurate to address when product variety is increased.

The results of the research support organisational decision-making by providing managers working in manufacturing environments with guidance on how to better manage heterogeneous market requirements and product variety ambitions. Specifically, the research provides managers working in different types of manufacturing facility with different customisation profiles, classified in the research using a five-stage sequence from pure standardisation to pure customisation, with evidence of how business process activities are affected by an increase in product variety. Within the overall evidence-set, managers are provided with the implications of variety increases on a comprehensive series of activities typically required for the effective organisation and management of different business processes. Such insight is particularly valuable for manufacturing concerns that are 
considering changing the heterogeneity of their product base through product variety increases in order to provide increased customer choice.

We do not claim mixed methods to be superior to single method approaches but we believe that for this study, in an under-researched and complex area, a mixed-methods approach provided insight which we believe we would not otherwise have gained if a single method had been adopted. We encourage researchers to carefully select their research designs and consider opportunities for mixing their methods to advance the rigour with which production research is undertaken.

There are some limitations associated with this research. First, our research primarily focused on the principal customisation type of a chosen product family in each manufacturing facility. However, mixed rather than single customisation types commonly occur across product families. The implications, trade-offs and synergies associated with such multiple scenarios have not been considered. Second, this study focused almost exclusively on manufacturing industries in the UK. This particularity may limit the ability to generalise the findings to other populations, considering competitive, environmental and cultural differences that exist between different countries and regions (Hughes and Morgan 2008). Also, the number of business process activities were unevenly distributed across the value chain of business processes. This skews the significance of the results towards business process activities rather than to the aggregated business processes. Also, the study asked respondents to gauge the impact of a product variety increase without distinguishing between a negative and a positive impact. It may be that not all costs and non-costs are negative and not all outcomes are positive as has been assumed in the application of the survey instrument. Also, business process activities, although fully elaborated upon in each of the case studies, were not defined in the survey and are therefore subject to the interpretation of the respondents. For simplicity, variety levels were measured by 
considering fundamental, intermediate and peripheral levels as having the same weight and, lastly, we assumed that manufacturers increase their product variety while remaining within the same customisation category. This would be expected for a typical product variety increase. An appropriate topic for future research concerns the examination of how manufacturers can optimise the provision of multiple products with different decoupling points and different degrees of customisation. In addition, we suggest deleterious business process performance explains business under-performance when product variety increases. Understanding the effects of variety-mitigating capabilities on business activity and business process performance is a necessary, future line of enquiry. In addition, replication studies are recommended to further validate the findings.

\section{Acknowledgements}

We sincerely and wholeheartedly thank each of the anonymous reviewers for the time and effort they have put into reviewing our paper and for the resulting sharpening and improvement of the paper's content and presentation.

\section{References}

Abegglen, J.C., Stalk, G., 1985. Kaisha, the Japanese corporation. New York: Basic Books. Agarwal, A., Shankar, R., Tiwari, M.K. 2006., Modeling the metrics of lean, agile and leagile supply chain: An ANP-based approach. European Journal of Operational Research, 173 (1), 211225.

Alford, D., Sackett, P., Nelder, G., 2000. Mass customisation: An automotive perspective. International Journal of Production Economics. 65 (1), 99-110.

Amaro, G., Hendry, L., Kingsman, B., 1999. Competitive advantage, customisation and a new taxonomy for non make-to-stock companies. International Journal of Operations \& Production Management. 19 (3/4), 349-371.

Anderson, D.M., 2004. Build-to-Order and Mass Customisation: The Ultimate Supply Chain Management and Lean Manufacturing Strategy for Low-Cost On-Demand Production without Forecasts or Inventory. Cambria, CA: CIM Press.

Anderson, S.W., 1995. Measuring the impact of product mix heterogeneity on manufacturing overhead cost. Accounting Review. 70 (3), 363-387.

Banker, R.D., Datar, S.M., Kekre, S., Mukbopadbyay, T., 1990. Cost of product and process complexity. In Measures of Manufacturing Excellence, edited by R. Kaplan, Boston, MA: Harvard Business press. 
Barroso, A., Giarratana. M.S., 2013. Product proliferation strategies and firm performance: the moderating role of product space complexity. Strategic Management Journal. 34 (12), 14351452.

Bayus, B.L., Erickson, G., Jacobson. R., 2003. The financial rewards of new product introductions in the personal computer industry. Management Science. 49 (2), 197-210.

Benjaafar, S., Kim. J.S., Vishwanadham. N., 2004. On the effect of product variety in productioninventory systems. Annals of Operations Research. 126 (1-4), 71-101.

Bozarth, C.C., Warsing, D.P., Flynn, B.B., Flynn. E.J., 2009. The impact of supply chain complexity on manufacturing plant performance. Journal of Operations Management. 27 (1), 78-93.

Chopra, S., 2003. Designing the distribution network in a supply chain. Transportation Research: Part E. 39 (2), 123-140.

Chopra, S., Meindl. P., 2007. Supply chain management: strategy, planning, and operation. Upper Saddle River, NJ: Pearson Prentice Hall.

Da Silveira, G., Borenstein, D., Fogliatto, F.S., 2001. Mass customisation: Literature review and research directions. International Journal of Production Economics. 72 (1), 1-13.

Davila, T., Wouters. M., 2007. An empirical test of inventory, service and cost benefits from a postponement strategy. International Journal of Production Research. 45 (10), 2245-2267.

Dillman, D.A., 2007. Mail and Internet Surveys, 2nd ed. Hoboken, NJ: John Wiley \& Sons Ltd.

Draganska, M., Jain. D.C., 2005. Product-line length as a competitive tool. Journal of Economics \& Management Strategy, 14 (1), 1-28.

Duray, R., Ward, P.T., Milligan, G.W., Berry. W.L., 2000. Approaches to mass customisation: configurations and empirical validation. Journal of Operations Management. 18 (6), 605625 .

ElMaraghy, H.A., Kuzgunkaya, O., Urbanic. R.J., 2005. Manufacturing systems configuration complexity. CIRP Annals - Manufacturing Technology. 54 (1), 445-450.

ElMaraghy, H., Schuh, G., ElMaraghy, W., Piller, F., Schonsleben, P., Tseng, M., Bernard. A., 2013. Product variety management. CIRP Annals - Manufacturing Technology, 62 (2), 629-652.

Er, M., MacCarthry. B., 2003. Investigating the impact of product variety in international supply chains: A simulation study. Paper presented at the 8th Annual Cambridge international manufacturing symposium.

Fisher, M., Ramdas, K., Ulrich. K., 1999. Component sharing in the management of product variety: A study of automotive braking systems. Management Science. 45 (3), 297-315.

Fisher, M.L., Ittner. C.D., 1999. The Impact of Product Variety on Automobile Assembly Operations: Empirical Evidence and Simulation Analysis. Management Science. 45 (6), 771-786.

Fisher, M.L., Jain, A., MacDuffie. J.P., 1995. Strategies for product variety: Lessons from the auto industry. In Redesigning the firm, edited by Bowman E., Kogut, B., NY: Oxford University Press.

Flynn, B.B., Flynn. E.J. 1999. Information-processing alternatives for coping with manufacturing environment complexity. Decision Sciences. 30 (4), 1021-1052.

Forza, C., Salvador. F. 2001. Information flows for high-performance manufacturing. International Journal of Production Economics. 70 (1), 21-36.

Forza, C., Salvador. F. 2002. Managing for variety in the order acquisition and fulfilment process: The contribution of product configuration systems. International Journal of Production Economics. 76 (1), 87-98.

Foster, G., Gupta. M. 1990. Manufacturing overhead cost driver analysis. Journal of Accounting and Economics. 12 (1-3), 309-337.

Frohlich, M.T., 2002. Methodological note: Techniques for improving response rates in OM survey research. Journal of Operations Management. 20 (1), 53-62.

Fujita, K. 2002., Product variety optimization under modular architecture. Computer-Aided Design, London Butterworth. 34 (12), 953-965.

Gerbing, D.W., Anderson. J.C., 1988. An updated paradigm for scale development incorporating unidimensionality and its assessment. Journal of Marketing Research. 25 (2), 186-192.

Gilmore, J.H., Pine-II. B.J., 1997. The four faces of mass customisation. Harvard Business Review. 75 (1), 91-101. 
Golicic, S.L., Davis. D.F., 2012. Implementing mixed methods research in supply chain management. International Journal of Physical Distribution and Logistics Management. 42 (8/9), 726-741.

Hayes, R.H., Wheelwright. S.C., 1984. Restoring our competitive edge: competing through manufacturing. New York: Wiley.

Hu, S.J., Weyand, J., Ko, L., ElMaraghy, H.A., Lien, T.K., Koren, Y., Bley, H., Chryssolouris, G., Nasr, N., Shpitalni. M., 2011. Assembly system design and operations for product variety. Annals- Cirp. 60 (2), 715-733.

Hu, S.J., Zhu, X., Wang, H., Koren. Y., 2008. Product variety and manufacturing complexity in assembly systems and supply chains. CIRP Annals - Manufacturing Technology. 57 (1), 45 48.

Hughes, P., Morgan. R. E., 2008. Fitting strategic resources with product-market strategy: Performance implications. Journal of Business Research Policy. 61 (4), 323-331.

Jiao, J., Tseng, M.M., Ma, Q., Zou. Y., 2000. Generic bill-of-materials-and-operations for highvariety production management. Concurrent Engineering Research and Applications. 8 (4), 297-321.

Jiao, J.X., Tseng. M.M. 1999. A methodology of developing product family architecture for mass customisation. Journal of Intelligent Manufacturing. 10 (1), 3-20.

Kekre, S., Srinivasan. K., 1990. Broader product line: A necessity to achieve success?. Management Science. 36 (10), 1216-1231.

Kotteaku, A.G., Laios, L.G., Moschuris. S.J., 1995. The Influence of product complexity on the purchasing structure. Omega. 23 (1), 27-39.

Krishnan, V., Gupta. S., 2001. Appropriateness and Impact of Platform-Based Product Development. Management Science. 47 (1), 52-68.

Lampel, J., Mintzberg. H., 1996. Customizing customisation. Sloan Management Review. 38 (1), 21-30.

Lee, H. L. 2002. Aligning supply chain strategies with product uncertainties. California Management Review. 44 (3), 105-119.

Lifang, W. 2007. Toward an understanding of the product variety decision: An integrative model. International Journal of Management. 24 (3), 499-504.

MacCarthy, B., Brabazon, P. G., Bramham, J. (2003). Fundamental modes of operation for mass customization. International Journal of Production Economics, 85 (3), 289-304.

MacDuffie, J. P., Sethuraman, K., Fisher. M. L., 1996. Product Variety and Manufacturing Performance: Evidence from the International Automotive Assembly Plant Study. Management Science. 42 (3), 350-369.

Martin, M. V., Ishii. K., 1996. Design for variety: A Methodology for understanding the costs of product proliferation, Paper presented at the ASME Design engineering technical conferences, DTM-1610, NY.

Martin, M. V., Ishii. K. 1997. Design for variety: development of complexity indices and design charts. Paper presented at the ASME Design engineering technical conferences, DFM-4359, CA.

Martin, M. V., Ishii. K., 2002. Design for variety: developing standardised and modularized product platform architectures. Research in Engineering Design. 13 (4), 213.

Matell, M. S., Jacoby. J., 1972. Is there an optimal number of alternatives for likert-scale items? Journal of Applied Psychology. 56 (6), 506-509.

Milgate, M. 2001.Supply chain complexity and delivery performance: an international exploratory study. Supply Chain Management. 6 (3), 106-118.

Mintzberg, H., Lamb, R., Shrivastava. P., 1988. Generic strategies: toward a comprehensive framework. Advances in Strategic Management. 5, 1-67.

Modrak, V., Marton., D., Bednar. S., 2014. Modeling and determining product variety for masscusotomised manufacturing. CIRP Conference on Assembly Technologies and System. 23, 258-263.

Montreuil, B., Poulin. M. 2005. Demand and supply network design scope for personalized manufacturing. Production Planning \& Control. 16 (5), 454-469. 
Naylor, J. B., Naim, M. M., Berry. D., 1999. Leagility: Integrating the Lean and Agile Manufacturing Paradigms in the Total Supply Chain. International Journal of Production Economics. 62 (12), 107-118.

Otero-Neira, C., Varela, J., Garcia. T., 2010. Competitive reaction to the introduction of a new product: An exploratory market signalling study. Journal of Strategic Marketing. 18 (5), 379394.

Patel, P.C., Jayaram, J., 2013. The antecedents and consequences of product variety in new ventures: An empirical study, Journal of Operations Management, 32 (1-2), 34-50.

Porter, M.E. 1985. Competitive advantage: creating and sustaining superior performance. New York: Free Press.

Porter, M.E. 1991. Towards a dynamic theory of strategy. Strategic Management Journal, 12 (1), 95117.

Poulin, M., Montreuil, B., Martel. A., 2006. Implications of personalization offers on demand and supply network design: A case from the golf club industry. European Journal of Operational Research. 169 (3), 996-1009.

Rajagopalan, S., Swaminathan. J.M., 2001. A Coordinated Production Planning Model with Capacity Expansion and Inventory Management. Management Science. 47 (11), 1562-1580.

Ramdas, K. 2003. Managing product variety: An integrative review and research directions. Production \& Operations Management. 12 (1), 79-101.

Randall, T., Ulrich. K., 2001. Product Variety, Supply Chain Structure, and Firm Performance: Analysis of the U. S. Bicycle Industry. Management Science. 47 (12), 1588-1604.

Randall, T.R., Morgan, R.M., Morton. A.R., 2003. Efficient versus Responsive Supply Chain Choice: An Empirical Examination of Influential Factors. Journal of Product Innovation Management. 20 (6), 430-443.

Ray, G., Barney, J.B., Muhanna. W.A., 2004. Capabilities, business processes, and competitive advantage: choosing the dependent variable in empirical tests of the resource-based view. Strategic Management Journal. 25 (1), 23-37.

Salvador, F., Forza, C., Rungtusanatham. M., 2002. Modularity, product variety, production volume, and component sourcing: theorizing beyond generic prescriptions. Journal of Operations Management. 20 (5), 549-575.

Salvador, F., Rungtusanatham, M., Forza. C., 2004. Supply-chain configurations for mass customisation. Production Planning \& Control. 15 (4), 381-397.

Scavarda, L.F., Reichhart, A., Hamacher, S., Holweg. M., 2010. Managing product variety in emerging markets. International Journal of Operations \& Production Management. 30 (2), 205-224.

Squire, B., Readman, J., Brown, S., Bessant. J., 2004. Mass customisation: the key to customer value? Production Planning \& Control. 15 (4), 459-471.

Srinivasan, M.M., Viswanathan. S., 2010. Optimal work-in-process inventory levels for highvariety, low-volume manufacturing systems. IIE Transactions. 42 (6), 379-391.

Stablein, T., Holweg, M., Miemczyk. J., 2011. Theoretical versus actual product variety: how much customisation do customers really demand?. International Journal of Operations \& Production Management. 31 (3), 350-370.

Stavrulaki, E., Davis. M., 2010. Aligning products with supply chain processes and strategy. International Journal of Logistics Management. 21 (1), 127-151.

Stern, I., Henderson. A.D., 2004. Within-business diversification in technology-intensive industries. Strategic Management Journal, 25 (5), 487-505.

Sutton, J., 2001. Technology and market structure: theory and history. Cambridge, Mass: MIT Press.

Syam, S.S., Bhatnagar. A., 2015. A decision support model for determining the level of product variety with marketing and supply chain considerations. Journal of Retailing and Consumer Services, 25, 12-21.

Tang, E.P.Y., Yam. R.C.M. 1996. Product variety strategy - an environmental perspective. Integrated Manufacturing Systems. 7 (6), 24-29.

Teddie, C. Tashakkori, A., 2009. Fundamentals of Mixed Methods Research, Sage Publications.

Thomas, C. 2011. Too Many Products: Decentralized Decision Making in Multinational Firms. American Economic Journal: Microeconomics. 3 (1), 280-306. 
Thonemann, U. W. Bradley. J. R., 2002. The effect of product variety on supply-chain performance. European Journal of Operational Research. 143 (3), 548-569.

Um, J., Lyons, A., Lam, H.K.S., Cheng, T.C.E., Dominguez-Pery. C., 2017. Product variety management and supply chain performance: A capability perspective on their relationships and competitiveness implications. International Journal of Production Economics. 187, 1526.

Venkatesh, V., Brown, S.A., Bala. H., 2013. Bridging the qualitative-quantitative divide: guidelines for conducting mixed methods research in information systems. MIS Quarterly. 37 (1), 2154.

Vollmann, T., Berry, W., Whybark, D., Jacobs. F., 2005. Manufacturing planning and control systems for supply chain management. NY: McGraw-Hill.

Wan, X., Sanders, N.R., 2017. The negative impact of product variety: Forecast bias, inventory levels, and the role of vertical integration. International Journal of Production Economics, 186, 123-31.

Wan, X., Evers, P., Dresner, M., 2012. Too much of a good thing: The impact of product variety on operations and sales performance. Journal of Operations Management, 30 (4), 316-324.

Wan, X., Dresner, M.E., Evers, P.T., 2014. Assessing the dimensions of product variety on performance: The value of product line and pack size. Journal of Business Logistics, 35 (3), 213-224.

Wenerfelt, B. 1984. A resource-based view of the firm. Strategic Management Journal, 5 (2), 171180.

Whang, S., Lee. H., 1998. Value of Postponement. In Product Variety Management: Research Advances, Boston: Kluwer Academic Publishers.

Xia, N., Rajagopalan. S., 2009. Standard vs. custom products: variety, lead time, and price competition. Marketing Science. 28 (5), 887-900.

Yeh, K.H. Chu. C.H., 1991. Adaptive Strategies for Coping with Product Variety Decisions. International Journal of Operations \& Production Management. 11 (8), 35-47.

Zhang, M., Chen, Y.J., Tseng. M.M., 2005. Distributed knowledge management for product and process variety in mass customisation. International Journal of Computer Applications in Technology. 23 (1), 13-30.

Zhang, X., Chen, R.Q., Ma. Y.B., 2007. An empirical examination of response time, product variety and firm performance. International Journal of Production Research. 45 (14), 3135-3150. 


\section{Appendix}

\section{Survey Questionnaire}

\section{$\underline{\text { Part A. Business Background information }}$}

A1. What is the main product or service of your firm?

$\square$ Food, beverage, tobacco

$\square$ Chemical and petroleum materials and products

$\square$ Wood and furniture

$\square$ Fabricated metal products

$\square$ Electronic parts and components

$\square$ Transport equipment

$\square$ Paper products

Basic metal products

Other

$\square$ Non-metal mineral products

$\square$ Computer and communication products

$\square$ Electrical machinery and equipment

$\square$ Textiles and leather

$\square$ Machinery and equipment

Clothing and footwear

A2. Level of product variety (Core product / family)

\begin{tabular}{|c|c|c|c|c|c|c|}
\hline \multicolumn{2}{|c|}{ Please tick one of the following } & $\mathbf{1 - 5}$ & $\begin{array}{c}\mathbf{6 -} \\
\mathbf{1 0}\end{array}$ & $\begin{array}{c}\mathbf{1 1}-\mathbf{1 6 -} \\
\mathbf{1 5}\end{array}$ & $\begin{array}{c}\text { Above } \\
\mathbf{2 0}\end{array}$ \\
\cline { 3 - 6 } & $\mathbf{1}$ & $\mathbf{2}$ & $\mathbf{3}$ & $\mathbf{4}$ & $\mathbf{5}$ \\
\hline 1 & Number of different core designs for your products & $\square$ & $\square$ & $\square$ & $\square$ & $\square$ \\
\hline 2 & $\begin{array}{c}\text { Number of different colours, sizes and technical options dependent on core } \\
\text { design }\end{array}$ & $\square$ & $\square$ & $\square$ & $\square$ & $\square$ \\
\hline 3 & Number of particular options and accessories independent of core design & $\square$ & $\square$ & $\square$ & $\square$ & $\square$ \\
\hline
\end{tabular}

A3. Type of customisation

\section{Please indicate how product or service customisation is mainly achieved in your firm. (Tick only} one)

1 We provide standard products that have pre-defined options and designs. Product customisation happens at the sales stage.

We provide products in which customers may customise product packaging, delivery schedules,

2 or delivery location. The actual product is standard with pre-defined options and designs. Customisation works at the sales and distribution stages.

We provide various types of products in which customers are offered a number of pre-defined 3 options. Products are assembled to customer order using standard components. Customisation is achieved at the assembly stage.

We provide various types of products in which customers are offered a number of pre-defined

4 designs. Products are manufactured to customer order. Customisation is achieved at the fabrication stage.

5 We provide a unique product design in which customer input is at the start of the design process. Products are designed to order. Customisation is achieved at the design stage. 
Part B. Impact of Product Variety

\begin{tabular}{|c|c|c|c|c|c|c|c|c|c|c|c|}
\hline \multirow{2}{*}{\multicolumn{2}{|c|}{$\begin{array}{l}\text { With reference to Part } \mathrm{A} \text { and based on previous } \\
\text { product variety increases }{ }^{1} \text {, please indicate the } \\
\text { relative impact of a product variety increase on each } \\
\text { of the following. (Refer to the notes below.) }\end{array}$}} & \multicolumn{8}{|c|}{ Lowest ${ }^{2}$} & \multicolumn{2}{|c|}{ Highest $^{2}$} \\
\hline & & 1 & 2 & 3 & 4 & 5 & 6 & 7 & 8 & 9 & 10 \\
\hline \multicolumn{12}{|c|}{ Negative Performance - Increases in Costs, Administration \& Resources } \\
\hline \multicolumn{12}{|c|}{ Engineering } \\
\hline 1 & Design complexity & $\square$ & $\square$ & $\square$ & $\square$ & $\square$ & $\square$ & $\square$ & $\square$ & $\square$ & $\square$ \\
\hline 2 & R\&D cost & $\square$ & $\square$ & $\square$ & $\square$ & $\square$ & $\square$ & $\square$ & $\square$ & $\square$ & $\square$ \\
\hline 3 & Unit cost of product & $\square$ & $\square$ & $\square$ & $\square$ & $\square$ & $\square$ & $\square$ & $\square$ & $\square$ & $\square$ \\
\hline 4 & Engineering design change cost & $\square$ & $\square$ & $\square$ & $\square$ & $\square$ & $\square$ & $\square$ & $\square$ & $\square$ & $\square$ \\
\hline \multicolumn{12}{|c|}{ Manufacturing } \\
\hline 5 & Quality control & $\square$ & $\square$ & $\square$ & $\square$ & $\square$ & $\square$ & $\square$ & $\square$ & $\square$ & $\square$ \\
\hline 6 & Manufacturing process cost & $\square$ & $\square$ & $\square$ & $\bar{\square}$ & $\square$ & $\bar{\square}$ & $\bar{\square}$ & $\square$ & $\square$ & $\square$ \\
\hline 7 & Set-up cost & $\square$ & $\square$ & $\square$ & $\square$ & $\square$ & $\square$ & $\square$ & $\square$ & $\square$ & $\square$ \\
\hline 8 & Direct labour cost & $\square$ & $\square$ & $\square$ & $\bar{\square}$ & $\square$ & $\bar{\square}$ & $\bar{\square}$ & $\square$ & $\square$ & $\square$ \\
\hline 9 & Process variety & $\square$ & $\square$ & $\square$ & $\square$ & $\square$ & $\square$ & $\square$ & $\square$ & $\square$ & $\square$ \\
\hline 10 & Part variety & $\square$ & $\square$ & $\square$ & $\square$ & $\square$ & $\square$ & $\square$ & $\square$ & $\square$ & $\square$ \\
\hline 11 & Manufacturing complexity & $\square$ & $\square$ & $\square$ & $\bar{\square}$ & $\square$ & $\bar{\square}$ & $\bar{\square}$ & $\square$ & $\square$ & $\square$ \\
\hline 12 & Supervision effort & $\square$ & $\square$ & $\square$ & $\square$ & $\square$ & $\square$ & $\square$ & $\square$ & $\square$ & $\square$ \\
\hline 13 & Scheduling comple & $\square$ & $\square$ & $\square$ & $\square$ & $\square$ & $\square$ & $\square$ & $\square$ & $\square$ & $\square$ \\
\hline 14 & Material cost & $\square$ & $\square$ & $\square$ & $\square$ & $\square$ & $\square$ & $\square$ & $\square$ & $\square$ & $\square$ \\
\hline 15 & Overhead cost & $\square$ & $\square$ & $\square$ & $\square$ & $\square$ & $\square$ & $\square$ & $\square$ & $\square$ & $\square$ \\
\hline 16 & Manufacturing lead time & $\square$ & $\square$ & $\square$ & $\square$ & $\square$ & $\square$ & $\square$ & $\square$ & $\square$ & $\square$ \\
\hline 17 & Process technology investment cost & $\square$ & $\square$ & $\square$ & $\square$ & $\square$ & $\square$ & $\square$ & $\square$ & $\square$ & $\square$ \\
\hline \multicolumn{12}{|c|}{ Procurement } \\
\hline 18 & Purchasing costs & $\square$ & $\square$ & $\square$ & $\square$ & $\square$ & $\square$ & $\square$ & $\square$ & $\square$ & $\square$ \\
\hline 19 & Order processing & $\square$ & $\square$ & $\square$ & $\square$ & $\square$ & $\square$ & $\square$ & $\square$ & $\square$ & $\square$ \\
\hline 20 & Purchased component variety & $\square$ & $\square$ & $\square$ & $\square$ & $\square$ & $\square$ & $\square$ & $\square$ & $\square$ & $\square$ \\
\hline \multicolumn{12}{|c|}{ Logistics } \\
\hline 21 & Work in-process inventory & $\square$ & $\square$ & $\square$ & $\square$ & $\square$ & $\square$ & $\square$ & $\square$ & $\square$ & $\square$ \\
\hline 22 & Finished goods inventory & $\square$ & $\square$ & $\square$ & $\square$ & $\square$ & $\square$ & $\square$ & \begin{tabular}{|l|} 
\\
\end{tabular} & $\square$ & $\square$ \\
\hline 23 & Inventory cost & $\square$ & $\square$ & $\square$ & $\square$ & $\square$ & $\square$ & $\square$ & $\square$ & $\square$ & $\square$ \\
\hline 24 & Purchased component inventory & $\square$ & $\square$ & $\square$ & $\square$ & $\square$ & $\square$ & $\square$ & $\square$ & $\square$ & $\square$ \\
\hline 25 & Delivery time & $\square$ & $\square$ & $\square$ & $\square$ & $\square$ & $\square$ & $\square$ & $\square$ & $\square$ & $\square$ \\
\hline 26 & Material handling cost & $\square$ & $\square$ & $\square$ & $\square$ & $\square$ & $\square$ & $\square$ & $\square$ & $\square$ & $\square$ \\
\hline 27 & Transportation cost & $\square$ & $\square$ & $\square$ & $\square$ & $\square$ & $\square$ & $\square$ & $\square$ & $\square$ & $\square$ \\
\hline \multicolumn{12}{|c|}{ Sales } \\
\hline 28 & Demand forecasting uncertainty & $\square$ & $\square$ & $\square$ & $\square$ & $\square$ & $\square$ & $\square$ & $\square$ & $\square$ & $\square$ \\
\hline \multicolumn{12}{|c|}{ Positive Performance } \\
\hline \multicolumn{12}{|c|}{ Customer satisfaction, sales \& competitive advantage } \\
\hline 1 & Customer satisfaction & $\square$ & $\square$ & $\square$ & $\square$ & $\square$ & $\square$ & $\square$ & $\square$ & $\square$ & $\square$ \\
\hline 2 & Sales / Market share & $\square$ & $\square$ & $\square$ & $\bar{\square}$ & $\square$ & $\bar{\square}$ & $\bar{\square}$ & $\square$ & $\square$ & $\square$ \\
\hline 3 & Competitive advantage & $\square$ & $\square$ & $\square$ & $\square$ & $\square$ & $\square$ & $\square$ & 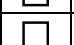 & 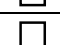 & 口 \\
\hline
\end{tabular}

Notes:

${ }^{1} \mathrm{~A}$ product variety increase is regarded as a typical extension to the range of the selected product family offered to customers. In A3, if you selected ' 1 ' an increase may be a new customer and delivery destination; for ' 2 ' it may be a new packaging formulation; for ' 3 ' ' it may be a new product option; for ' 4 ' it may be a new product derived from an existing design; for ' 5 ' it may be a new, unique product.

${ }^{2} 10$ would indicate a very high material effect on the business process activity; 1 would indicate a minimal effect. 